\title{
PENGARUH BEBERAPA MEDIA SEMAI TERHADAP PERTUMBUHAN STEK AKAR TANAMAN SUKUN (Aartocharpus communis forst)
}

\author{
Rofika Nofri Yandra ${ }^{1}$, Nursida ${ }^{2}$, Zinatal Hayati ${ }^{3}$ \\ ${ }^{1}$ Program Studi Agroteknologi, Fakultas Pertanian, Universitas Islam Indragiri, Tembilahan \\ Email: namapenuliskoresponden@ft.uak.ac.id (korespondensi)
}

\begin{abstract}
Research on the influence of some seedling media on breadfruit root cuttings has been carried out at the green house of the Faculty of Agriculture on Jl. This research is to know the effect of some combination of seed media on the growth of breadfruit root cuttings and to know the combination of media suitable for the growth of breadfruit root cuttings.

The design of this study used a randomized block design with six treatments consisting of a combination of sand and manure (2: 2: 1), sand. Manure and peat soil 1: 1: 1, manure sand and sawdust 1: 1: 1, manure sand and sawdust charcoal 1: 1: 1, sand, rice husk fertilizer 1: 1: 1, all six treatments repeated as many as 3 times the parameters observed in this study were shoot length, leaf length, number of leaves, shoot diameter, percentage of growth, percentage of life, number of roots, root weight, and indices of seed quality. The variance results tested in f table 5\% showed a significant effect on the number of roots of dry root weights and seed quality index and the effect was not significant on the shoot length meters. Leaf length, number of leaves, shoot percentage, growth percentage and growth percentage.
\end{abstract}

Keywords:Breadfruit, media, cutting.

\begin{abstract}
Abstrak
Penelitian pengaruh beberapa media semai terhadap tumbuhan stek akar tanaman sukun telah dilaksanakan di green house fakultas pertanian jl.lintas provisi tembilahan barat kematan tembilahan hulu selama 4 bulan (mei-agustus). Penelitian ini untuk mengahtahui pengaruh beberapa kombinasi media semai terhadap pertumbuhan stek akar tanaman sukun dan untuk mengetaui kombinasi media yang cocok untuk pertumbuhan stek akar sukun.

Rancangan penelitian ini menggunakan rancangan acak kelompok dengan enam perlakuan yang terdiri dari kombinasi pasir dan pupuk kandang (2:2:1), pasir. Pupuk kandang dan tanah gambut $1: 1: 1$, pasir pupuk kandang dan serbuk gergaji $1: 1: 1$, pasir pupuk kandang dan arang serbuk gergaji $1: 1: 1$, pasir, pupuk sekam padi $1: 1: 1$, keenam perlakuan diulang sebanyak 3 kali parameter yang di amati oada peneliyian ini adalah panajng tunas, panjang daun, jumlah daun, diameter tunas, persentase tumbuh, persentase hidup, jumlah akar bobot akarkering dan indiks mutu bibit.

Hasil sidik ragam yang diuji pada $f$ tabel $5 \%$ menunjukkan pengaruh yang nyata pada jumlah akar bobot akar kering dan indeks mutu bibit dan pengaruh yang tidak nyata pada para meter panjang tunas. Panjang daun, jumlah daun, diameter tunas persentasi tmbuh dan persentasi tumbuh.
\end{abstract}

Kata kunci: sukun,Media, Stek

\section{PENDAhuluan}

Buah sukun berpotensi menjadi penganti beras, karena buah sukun memiliki karbohidrat yang tinggi, tingginya kandungfan karbohidrat yang terdapat pada buah sukun ini sehingga buah sukun dpat diolah menjadi tepung dan dimanfaatkan sebagai tepung terigu.

Tanaman sukun hampid dapat hidup disemua jenis tanah, oleh karena itu tanaman sukun memiliki daerah penyebaran yang sangat luas. Tanah podsolik merah kuning, tanah kapur, tanah alluvial, tanah berpasir dan bahkan 
tanah gambut sukun mampu tumbuh dengan baik (Pitojo 1992).

Kabupaten Indragiri Hilir memiliki dataran yang luas, dan sebagian besar daratannya terdiri dari tanah gambut. Karena sukun mampu hidup baik digambut sehingga dengan demikian sukun dapat dibudidayakan secara komersil dan bisa dijadikan tanaman sela dikebun kelapa Kabupaten Idragiri Hilir.

Teknik stek akar dilakukan untuk memperoleh bibit dalam jumlah yang besar karena bahan yang digunakan dapat diperolehdalam jumlah banyak serta pelaksanaannya cukup mudah dan biayanya relative murah. Pengambilan akar dilakukan dengan menggali akar kemudian dipotong sepanjang 0,5 - $1 \mathrm{~m}$. Apabila pengambilan bahan stek dilakukan ditempat yang jauh dari lokasi persemaian maka stek dijaga supaya tidak kering dibungkus menggunakan pelepah pisang atau karung goni yang basah. Setelah ditanam segera dilakukan penyiraman kemudian bedengan ditutup dengan sungkup plastik. Setelah satu bulan dalam bedengan, stek akar mulai menumbuhkan tunas. Pada bulan ketiga akar sudah tumbuh namun daunnya masih berwarnaa kekuningan. Pada saat ini sungkup plastik sudah dapat dibuka secara bertahap agar bibit tidak layu dan 1-2 minggu kemudian sungkup sudah dapat dibuka sepenuhnya (Irwanto, 2006).

Permasalahan dalam pengadaan bibit sukun yaitu sulitnya menentukan komposisi media yang sesuai untuk persemaian stek akar tanaman sukun dan mendapatkan bibit sukun dalam jumlah yang banyak dan seragam. Oleh karena itu dilakukan penelitian dengan perlakuan beberapa media semai diantaranya pasir dan pupuk kandang sebagi kontrol karena sifat pasir yang cepat kering karena memudahkan proses pengankatan bibit tanaman yang dianggap sudah cukup umur untuk dipindahkan kemdeia lain. Kemudian kombinasi antara pasir , tanah gambut dan pupuk kandang, kombinasi antara pasir, sekam padi dan pupuk kandang, kombinasi pasir dengan arang sekam padi, kombinasi antara pasir dengan serbuk gergaji, tujuan dari perlakuan ini yaitu untuk mengetahui media mana yang cepat dan baik pertumbuhannya.

Berdasarkan hasil penelitian

(Adinugraha dkk, 2007) bahwa pertumbuhan semai stek pucuk Eucalyptus pellita F, Muel memberikan respon pertumbuhan terbaik pada media pasir sungai dibanding pada media serbuk sabut kelapa, campuran pasir dan sabut kelapa (1:1).

Berdasarkan alas an diatas penulis tertarik untuk melakukan penelitian yang berjudul Pengaruh Beberapa Media Semai Terhadap Pertumbuhan Stek Akar Tanaman Sukun (Artocarpus communis Forst).

\section{TINJAUAN PUSTAKA}

\subsection{Tanaman Sukun}

Tanaman sukun baik dikembangkan didataran rendah hingga ketinggian 1200 m dpl yang bertipe ikim basah. Curah hujan antara 2.000-3.000 mm per tahaun. Tanah alluvial yang mengandung banyak bahan organik disenangi oleh tanaman sukun. Derajat keasaman tanah sekitar 6-7. Tanaman sukun relatif toleran $\mathrm{pH}$ rendah, relatif tanah kekeringan, dan tanah naungan. Bunganya keluar dari ketiak daun pada ujung cabang dan ranting. Bungan jantan berbentuk tongjat panajang yang disebut ontel. Bunga betina berbentuk bulat bertangkai pendek (bebal) seperti pada nangka. Bunga betina mrupakan bunga majemuk sinkarpik seperti pada nangka. Kulit buah menonjol rata sehingga tampak tidak jelas yang merupakan bekas putik dari bungan sinkarpik. Pada buah keluwih, tonjolan pada kulit buah merupakan duri yang lunak. Penyerbukan bunga dibantu oleh angin, sedangkan serangga yang sering berkunjung kurang berperan dalam penyerbukan bunga. Pada buah sukun, walaupun terjedi penyerbukan, perubahannya mengalami kegagalan sehingga buah yang terbentuk tidak berbiji (Anionimus, 2008).

Tanaman sukun merupakan tanaman hutan yang tingginya mencapai $20 \mathrm{~m}$. Kayunya lunak, kulit kayunya beserat kasar, dan semua bagian tanaman bergetah encer. Daunnya lebar sekali, bercegap menjari dan berbulu kasar. Bunganya keluar dari ketiak daun pada uung cabang dan ranting, tetapi masih dalam satu pohon (berumah satu).

Buah sukun berbentuk bulat agak lonjong, warna kulit buah agak hijau muda sampai kekuning-kuningan, ketebalan kulit halus antara 1-2 mm. Buah muda berkulit kasar dan buah tua berkulit halus. Daging buah berwarna putih dengan ketebalan sekitar $7 \mathrm{~cm}$. Teksturnya kompak dan berserat halus. Rasanya agak manis dan memiliki aroma yang spesifik. Diameter buah kurang lebih $26 \mathrm{~cm}$. Tangakai buah sekitar $5 \mathrm{~cm}$. Berat buah dapat 
mencapai $4 \mathrm{~kg}$. Sukun diklasifikasikan sebagai berikut:

Subkingdom :Tracheobionta (Tumbuhan berpembuluh)

Subdivisi :Spermatophyta

(Menghasilkan biji)

Divisi : Magnoliophyta (Tumbuhan berbunga)

Kelas : Magnoliopsida (Berkeping dua / dikotil)

Sub Kelas : Dilleniidae

Ordo : Urticlas

Familli : Moraceae (Suku nagka-nagkaan)

Genus : Artocarpus

Spesies : Artocarpus communis Forst

\subsection{Perbanyakan stek akar tanaman sukun}

Benih sukun dengan cara stek akar merupakan alternative utama yang di pakai para prmbenih. Cara ini timbul karena secara alami akar sukun mampu menumbuhkan tunas sebagai tanaman baru keuntungan pembenihan dengan cara ini adalah mampu menghasilkan benih sekaligus dalam jumlah yang besar dan seragam pertumbuhan nya(Angkasa,1994). Akar yang dipergunakan adalah akar besar maupun akar cabang. Tanaman tua lebih banyak menghasikan bibit

di bandingkan dengan tanaman muda. Namun dari tanaman muda aka di peroleh tanaman yang lebih cepat pertunasan nya dan rendemennya stek akar yang tumbuh lebih tinggi dari pada tanaman tua(Pitojo,1992). Untuk merasangsang pertumbuhan akar, stek ah 4 sendok $f$ di masukkan 4 sendok makan dalam baskom plastik ditambahkan 4 sendok makan air setelah kental di oleskan pada bagian bawah stek akar. Proses selanjutnya stek akar yang sudah diberi hormon peransang tumbuh di semai didalam bedengan pasir bedengan sebaiknya diberi atap daun kelapa atau daun alang-alang untuk mengurangi penguapan jarak tanam dalam bedengan ini cukup rapat 3-5 cm, lakukan penyiraman secara teratur pagi dan sore hari untuk meenuhi kelembapan yang di butuhkan. Semai dalam polybag atau plastik yang dapat disisikan tanah pupuk kandang dan pasir dengan perbandingan 2:2:1 masukan media 3/4 bagian plastik atau polybag. Kemudian stek akar di semaikan, tindakan penyiraman tetap harus dilakukan. Setelah 1,5 bulan dalam polybag, stel menumbukan tunas daun selain itu, akar nya pun sudah terbanrtuk(Angkasa 1994). Media taman yang digunakan pasir, pupuk kandang, tanah gambut, serbuk gergaji, arang serbuk gergaji, sekam padi dan arang sekam padi.

\section{METODOLOGI PENELITIAN}

\subsection{Tempat dan waktu}

Penelitian ini di laksanakan di green house fakultas pertanian jl.lintas provinsi Tembilahan Barat kecamatan Tembilahn Hulu. Dan dilaksanakan selama 4 bulan Mei 2013 dan berakhir pada bulan Agustus 2013.

\subsection{Bahan dan alat}

Bahan yang diperlukan dalam penelitian ini adalah sebagi berikut: Bibit stek akar sukun yang diambil dari umur 7 tahun, gelas teh poci, rootone $f$, pasir cor, pupuk kandang, seam padi, tanah gambut, arang sekam padi, srbuk gergaji dan arang serbuk gergaji. Sedang kan alat tang diperlukan dalam penelitian ini: parang, cangkul, meteran, timbangan, pisau cutter, kalkulator, gembur, ember, gergaji, sekop, sarung tangan , tali rapia, bamboo lebel, dan alat tulis

\subsection{Metode penelitian}

Penelitian ini menggunakan Rancangan Acak Lengkpa (RAK) fsktor tunggal dengan 6 perlakuan dan 3 ulangan. Jumlah plot percobaan sebanyak 18 plot, pada masing-masing plot terdiri dari 6 tanaman. 1 tanaman dijadikan sebagai tanaman sampel, jumlah keseluruhan adalah $18 \times 6=108$ tanaman.

Adapun perlakuan percobaanya adalah sebagai berikut :

$\mathrm{A}=$ Pasir + Pupuk kandang $(2: 1(\mathrm{v} / \mathrm{v}))$

$\mathrm{B}=$ Pasir + Pupuk kandang + Gambut $(1: 1: 1(\mathrm{v} / \mathrm{v}))$

$\mathrm{C}=$ Pasir + Pupuk kandang + Serbuk gergaji $(1: 1: 1(\mathrm{v} / \mathrm{v}))$

$\mathrm{D}=$ Pasir + Pupuk kandang + Arang serbuk gergaji $(1: 1: 1(\mathrm{v} / \mathrm{v}))$

$E=$ Pasir + Pupuk kandang + Sekam padi $(1: 1: 1(\mathrm{v} / \mathrm{v}))$

$\mathrm{F}=$ Pasir + Pupuk kandang + Arang sekam padi $(1: 1: 1(\mathrm{v} / \mathrm{v}))$

Keterangan : v/v : volume / volume untuk takaran perbandingan perlakuan.

\subsection{Analisis Data}

Data yang diperoleh dari hasil pengamatan yang dianalisis secara statistic dengan menggunakan sidik ragam model linear sebagai berikut : $Y i j=\mu+\mathrm{Ti}+\mathrm{Bi}+€_{\mathrm{ij}}$

Keterangan :

Yij = Respon atau nilai pengamatan dari perlakuan ke 1 dan ulanagn ke- $j$

$\mu=$ Nilai tengah umum

$\mathrm{Ti}=$ Pengaruh perlakuan ke-1 


\begin{tabular}{l}
\hline ISSN:25282956 \\
\hline $\mathrm{Bi}=$ Banyak kelompok ke-1 \\
$€_{\mathrm{ij}=\text { Pu }}$ Pengaruh galat percobaan dari \\
perlakuan ke-1 dan ulangan ke-j
\end{tabular}

Untuk mrngrtahui perbedaan antar perlakuan dilakukan uji lanjut Beda nyata Jujur (BNJ) pada taraf 5\%.

\subsection{Pelaksanaan Penelitian}

\subsubsection{Pembuatan Naungan}

Penelitian ini membutuhkan naungan untuk menjaga kelembaban media, naungan dibuat dari daun kelapa seluas tempat berbagai media yang telah disiapkan.

3.5.2 Persiapan Media Tanam

Media yang digunakan dalam penelitian ini adalah komposisi pasir, pupuk kandang, tanah gambut, serbuk gergaji, arang serbuk gergaji sekam padi dan arang sekam padi.

3.5.3. Pemasangan Lebel

Lebel yang telah disiapkan akan dipasang sesuia dengan lay out penelitian dengan perlakuan masing-masing ulanagan.

3.5.4. Pemiloihan bahan stek

Stek akar yang akan diambil berasal dari akar leteral dari pohon induk yang berumur diatas 7 tahun, dengan diameter $1,5-3,0 \mathrm{~cm}$.

3.5.5 Penanaman

Akar lateral sepanjang $15-20 \mathrm{~cm}$ di tanam kedalam media yang telah disiapkan, sebelum stek ditanamn bagia meruncing dari potongan stek diolesi dengan pasta rootone $\mathrm{F}$, lalu ditanam kedalam media dengan kedalaman $8 \mathrm{~cm}$, setelah stek ditanam kedalam media kemudian disungkup dengan plastic transparan untuk menjaga kelembaban $8 \mathrm{~cm}$. Setelah stek ditanam kedalam kedalam media kemudian disungkup dengan plastic transparan untuk menjaga kelembaban.

\subsubsection{Perawatan}

Perawatan bertujuan agar tanaman yang disemai tumbuh subur seperti yang diharapkan, adapun perawatan yang di lakukan dalam penelitian anatar lain:

a. Penyiraman dilakuakan 2 kali sehari yaitu pagi dan sore hari.

b. Pengendalian Hama Terpadu (PHT) yaitu melakukan pengamatan terhadap keberadaan dan perkembangan hama dan penyakit dan apabila telah mencapai diambang ekonomi maka dilakukan pengendalian dengan menggunakan insektisida azodrin 75 EC dengan bahan aktif monokromofos.

c. Pemangkasan dilakukan pada saat tanamn berumur 2 bulan setelah tanam, yaitu dengan cara memotong tunas yang tumbuh lebih dari 1 dengan meninggalkan satu yang terbaik dari seluruh tunas yang tumbuh.

\subsection{Pengamatan}

3.6.1. Panjang Tunas $(\mathrm{cm})$

Panjang tunas yang tubuh diamati pada akhir penelitian, cara pengukurannya mulai dari awal muncul tunas sampai pucuk tunas teratas.

3.6.2. Panjang Daun (cm)

Penghitungan panajng daun dilakukan pada akhir penelitian, dengan cara memilih daun terpanjang dari tanaman sampel dan mengukur panjangnya.

3.6.3. Jumlah Daun (helai)

Penghitungan jumlah daun dilakukan pada akhir penelitian, yaitu dengan menghitung jumlah keseluruhan daun pada tanaman sampel.

3.6.4. Diameter tunas $(\mathrm{mm})$

Penghitungan diameter tunas dilakukan pada akhir penelitian, yaitu mengukur diameter terbesar dari bagian batang tunas yang tmbuh dengan menggunakan jangka sorong.

3.6.5. Peresentase tumbuh (\%)

Presentase tumbuh dihitung pada minggu ke- 8 dengan kriteria tunas tumbuh $50 \%$ dari jumlah 1 plot percobaan. Penghitungan presentase tumbuh dapat dihitung dengan rumus :

3.6.6. Persentase Hidup (\%)

Persentase hidup diperoleh dengan menghitung stek yang hidup pada minggu terakhir percobaan, dengan kriteria stek tetap hijau dan berakar. Persentase idup dapat dihitung dengan rumus sebagai berikut:

3.6.7. Jumlah akar

Jumlah akar dapat dihitung pada akhir penelitian dengan cara membongkar tanaman sampel pada tiap plot.

3.6.8. Bobot akar kering (gram)

Bobt akar kering dihitung dengan cara mencabut tanaman sampel pada tiap plot percobaan kemudian dibersihkan dan dioven dengan suhu $65^{\circ} \mathrm{C}$ selama 36 jam, dan setelah itu ditimbang bobotnya.

3.6.9. Indeks mutu bibit

Indeks mutu bibit dihitung untuk menentukan layak dan tidak layaknya bibit yang akan 
dipindahkan kelapangan, adapun rumus indeks mutu bibit yang dipakai oleh (Roller 1960) dalam (Dodi, 2007) adalah sebagai berikut:

Keterangan :

- Berat kering total : didapat dari hasil penimbangan akar, batang dan daun tanaman yang telah dioven selama 36 jam dengan suhu $65^{\circ} \mathrm{C}$.

- Tinggi : didapat dari hasil pengukuran tinggi tunas / tinggi tanaman sampel.

- Diameter : didapat dari hasil pengukuran diameter tunas.

- Berat kering tajuk : didapat dari hasil penimbangan berat kering tajuk yaitu batang dan daun tanaman sampel.

- Berat kering akar : didapat dari hasil penimbangan akar keing tanaman sampel.

Dari hasil yang didapat dari keterangan diatas kemudian dikalikan 100\% maka didapatlah hasil indeksnmutu bibit untuk tiap tanaman sampel.

Indek mutu bibit dihitung untuk mendapatkan nilai tiap satu plot percobaan kemudian dicari dengan menggunakan statistik.

\section{DAN PEMBAHASAN}

\subsection{Panjang Tunas (cm)}

Hasil analisisi sidik ragam pengaruh beberapa media semai terhadap oertumbuhan stek akar tanaman sukun tidak berpengaruh nyata pada pengamatan panjang tunas pada stek akar tanaman sukun. Rata-rata panjang tunas stek akar tanaman sukun yang diberikan sebagai media tanam yang dapat dilihat pada tabel 1 dibawah ini.

\begin{tabular}{|l|l|}
\hline Perlakuan & $\begin{array}{l}\text { Rata- } \\
\text { rata }\end{array}$ \\
\hline $\begin{array}{l}\text { (Pasir, dan Pupuk kandang) dan Tanah } \\
\text { (Pasir, Pupuk Kandang dan }\end{array}$ & $12.60 \mathrm{a}$ \\
\cline { 3 - 3 } $\begin{array}{l}\text { Gambut ) } \\
\text { (pasir, pupuk kandang, dan serbuk }\end{array}$ & $11.50 \mathrm{a}$ \\
$\begin{array}{l}\text { gergaji) } \\
\text { (pasir, pupul kandang, dan arang }\end{array}$ & $14.13 a$ \\
$\begin{array}{l}\text { serbuk gergaji) } \\
\text { (pasir, pupuk kandang, dan sekam } \\
\text { padi) } \\
\text { (pasir, pupuk kandang, dan arang } \\
\text { sekam padi) }\end{array}$ & $10.33 a$ \\
\cline { 2 - 3 }
\end{tabular}

Angka-angka yang di ikutidakti o leh huruf pada kolom yang sama tidak berbeda nyata menurut BNJ pada taraf 5\%

Dari data tabel 1 diatas menunjukan bahwa pengaruh beberapa media semai tidsk berbeda nyata terhadap rata-rata panjang tunas stek akar tanaman sukun, namun demikian secara angka perlakuan pasir, pupuk kandang dan arang sekam padi memberikan panjang tunas terpanjang $15.27 \mathrm{~cm}$. hal di sebabkan karena adanya pengaruh pada agi kombinasi media yang di berikan pada perlakuan tersebut dan hormone yang terkandung pada tanah yang mapu memberikan pertumbuhan yang cukup baik bagi tanaman, serta aerase dan draenase baik intuk tanah. Arang sekam padi berperan daklam memperbaiki sifik tanah,kimia dan biologi tanah. Arang sekam pouros, ringan, dan tidak kotor mampu mengentrol sirkulasi udara dalam media serta unsur hara yang teerkandung dari kombinasi pasir, pupuk kandang dan arang sekam padi yang mampu meningkatkan hormone yang cukup serta sifat fisik tanah dan kimia yang terdapat pada kombinasiyang mengakibatkan tanah menjdi subur sehingga tanaman mudah tumbuh dan berkembang. Menurut (Adi nugraha, 2009). Selanjut nya dilihat dari data tabel 1 pada perlakuan pasir, pupuk kandang dan arang sekam padi mampu memberikan pertumbuhan terbaik yaitu $15.27 \mathrm{~cm}$. hal ini di sebabkan karena arang sekam padi mapu memperbaiki sifat fisik tanah dan kimia tanah sehingga membuat pertumbuhan tanaman menjadi baik. Dan unsur hara yang terkandung dalam ketiga kombinsi antara pasir,pupuk kandang dan arang sekam padi mampu memberikan cadangan mkanan didlam taah yang nanti di serap oleh tanaman.

\section{2. panjang daun $(\mathrm{cm})$}

hasil analisis sidik ragam pengaruh beberapa media semai terhadap pertumbuhan stek akar tanaman sukun menunjukkan pengaruh tidak nyata terhadap pengamatan pannjang daun (lampiran $3 \mathrm{~b}$ ) rata-rata panjang daun stek akar tanaman sukun dari berbagai media taman dapat dilihat pada tabel 2. dibawah ini.

\begin{tabular}{|c|c|}
\hline Perlakuan & $\begin{array}{l}\text { Rata- } \\
\text { rata }\end{array}$ \\
\hline (Pasir, dan Pupuk kandang) & $11.7 a$ \\
\hline (Pasir, Pupuk Kandang dan & 13.0.a \\
\hline $\begin{array}{l}\text { Gambut ) } \\
\text { (nasir punuk kandana dan serbuk }\end{array}$ & 124 \\
\hline $\begin{array}{l}\text { gergaji) } \\
\text { gerguk kandang, dan serbuk }\end{array}$ & $\begin{array}{l}12.4 \mathrm{a} \\
12.0 \mathrm{a}\end{array}$ \\
\hline $\begin{array}{l}\text { (pasir, pupul kandang, dan arang } \\
\text { serbuk gergaii) }\end{array}$ & a 111 \\
\hline (pasir, pupuk kandang, dan sekam & \\
\hline $\begin{array}{l}\text { (pasir, pupuk kandang, dan arang } \\
\text { sekam padi) }\end{array}$ & $15.3 \mathrm{a}$ \\
\hline
\end{tabular}

Angka-angka yang di ikutidakti o leh huruf pada kolom yang sama tidak berbeda nyata menurut $B N J$ pada taraf $5 \%$ 
Dari data tabel 2 menunjukan bahwa pengaruh beberapa medea semai tidak berbeda nyata terhadap panajng daun stek akar tanaman sukun. Akan tetapi secara angka-angka panjang daun tertinggi 15. 3 $\mathrm{cm}$. hal ini di sebabkan karena daya karena serap unsur hara pada tanaman berjalan dengan baik,karena pada kombinasi peralkuan pasir, pupuk kandang dn arang sekam padi mampu menyediakan unsur hara yang baik bagi tanaman. Dan di tambah oleh (Mashudi, 2008) bahwa faktor penting dalam pengaturan fisilogis pertumbuhan bibit adlah penyinaran ketersediaan nitrogen dan air dalam tanah . karena pada masamasa ini tanaman banyak membutuhkan unsur hara bagi pertumbuhan dan perkembangan tanaman itu sendiri, seperti pertumbuhan daun, perpanjangan tunas dan pembesaran batangtunas serta pertamahan akar.

\subsection{Jumlah Daun}

Hasil analisis sidik ragam pengaruh beberpa media semai terhadap pertumbuhan stek akar tanaman sukun menunjukkan pengaruh yang tidak nyata terhadap pengamatan jumlah daun (lampiran 3c). rata jumlah daun stek akar tnaman sukun dari berbagai media tanam dapat dilihat pada tabel 3.

\begin{tabular}{|c|c|}
\hline Perlakuan & $\begin{array}{l}\text { Rata- } \\
\text { rata }\end{array}$ \\
\hline (Pasir dan Punuk kandana) & $5.2 \mathrm{a}$ \\
\hline \multirow{2}{*}{$\begin{array}{l}\text { (Pasir, Pupuk Kandang dan Tanah } \\
\text { Gambut ) } \\
\text { (pasir, pupuk kandang, dan serbuk }\end{array}$} & $5.1 \mathrm{a}$ \\
\hline & $3.5 \mathrm{a}$ \\
\hline \multirow{2}{*}{$\begin{array}{l}\text { gergaji) } \\
\text { (pasir, pupul kandang, dan arang } \\
\text { serbuk gergaji) } \\
\text { (pasir, pupuk kandang, dan sekam }\end{array}$} & $2.1 \mathrm{a}$ \\
\hline & $4.7 \mathrm{a}$ \\
\hline $\begin{array}{l}\text { padi) } \\
\text { (pasir, pupuk kandang, dan arang } \\
\text { sekam padi) }\end{array}$ & $4.3 \mathrm{a}$ \\
\hline
\end{tabular}

Angka-angka yang di ikutidakti o leh huruf pada kolom yang sama tidak berbeda nyata menurut BNJ pada taraf $5 \%$

Dari tabel 3 di atas terlihat bahwa setiap perlakuan menunjukan tidak berbeda nyata, akan tetapi di lihat dari rata-rata perlakuan pasir dan pupuk kandang memiliki angka tertinggi 5.2 $\mathrm{cm}$. hal ini diduga karena pada pasir mempunyai sift porous, mampu menahan air dan cepat kering serta memiliki aerase dan drainase yang baik untu media taman , menurut (Aninimous, 2013)

\subsection{Diameter daun}

Hasil analisis sidik ragam pengaruh beberpa media semai terhadap pertumbuhan stek akar tanaman sukun menunjukkan pengaruh yang tidak nyata terhadap pengamatan diameter daun (lampiran 3d). rata jumlah daun stek akar tnaman sukun dari berbagai media tanam dapat dilihat pada tabel 4.

\begin{tabular}{|c|c|}
\hline Perlakuan & $\begin{array}{l}\text { Rata- } \\
\text { rata }\end{array}$ \\
\hline \multirow{6}{*}{$\begin{array}{l}\text { (Pasir, dan Pupuk kandang) } \\
\text { (Pasir, Pupuk Kandang dan Tanah } \\
\text { Gambut) } \\
\text { (pasir, pupuk kandang, dan serbuk } \\
\text { gergaji) } \\
\text { (pasir, pupul kandang, dan arang } \\
\text { serbuk gergaji) } \\
\text { (pasir, pupuk kandang, dan sekam } \\
\text { padi) pupuk kandang, dan arang } \\
\text { (pasir, pun } \\
\text { sekam padi) }\end{array}$} & $2.67 \mathrm{a}$ \\
\hline & $3.00 \mathrm{a}$ \\
\hline & $3.00 \mathrm{a}$ \\
\hline & $2.67 a$ \\
\hline & $2.33 \mathrm{a}$ \\
\hline & $3.00 \mathrm{a}$ \\
\hline
\end{tabular}

Angka-angka yang di ikutidakti o leh huruf pada kolom yang sama tidak berbeda nyata menurut BNJ pada taraf 5\%

Dilihat dari rata-rata tabel 4 di tas masing perlakuan menunjukan tidak berbeda nyata , namun dapat dilihat dari rata-rata 3 perlakuan yang sam angka nya. Akan tetapi setelahdilakukan secara BNJ terlihat angka trtinggi yaitu pada perlakuan pasir, pupuk kandang dan tanah gambut. Hal ini di sebab kan tinggi nya suhu yang terdapat dalam green house yang menyebabkan cepat pertumbuhan stek akar sukun dan mempercepat diameter tunas, serta unsur hara yang tersedia pada bibit stek akar sukun yang mamou memenuhi kebuthan tanaman selama masa pembibitan hingga pembentukan akar yang mana sebagi penyerap unsur hara yang terdapat pada media tanam.

\subsection{Persentase tumbuh}

Hasil analisis sidik ragam pengaruh beberpa media semai terhadap pertumbuhan stek akar tanaman sukun menunjukkan pengaruh yang tidak nyata terhadap pengamatan persentase tumbuh (lampiran 3e). rerata persentase tumbuh dari stek akar tanaman sukun dari berbagai perlakuan dapat dilihat pada tabel 5 .

\begin{tabular}{|c|c|}
\hline Perlakuan & $\begin{array}{l}\text { Rata- } \\
\text { rata }\end{array}$ \\
\hline \multirow{6}{*}{$\begin{array}{l}\text { (Pasir, dan Pupuk kandang) } \\
\text { (Pasir, Pupuk Kandang dan Tanah } \\
\text { Gambut) } \\
\text { (pasir, pupuk kandang, dan serbuk } \\
\text { gergaji) } \\
\text { (pasir, pupul kandang, dan arang } \\
\text { serbuk gergaji) } \\
\text { (pasir, pupuk kandang, dan sekam } \\
\text { padi) } \\
\text { (pasir, pupuk kandang, dan arang } \\
\text { sekam padi }\end{array}$} & $54.89 \mathrm{a}$ \\
\hline & $38.44 \mathrm{a}$ \\
\hline & $46.50 \mathrm{a}$ \\
\hline & $39.17 \mathrm{a}$ \\
\hline & $27.78 \mathrm{a}$ \\
\hline & $50.00 \mathrm{a}$ \\
\hline $\begin{array}{l}\text { Angka-angka yang di ikutidakti o leh } \\
\text { kolom yang sama tidak berbeda nya } \\
\text { BNJ pada taraf } 5 \%\end{array}$ & \\
\hline
\end{tabular}


Dari tabel 5 diatas ddapat dilihat setiap perlakuan tidak berbeda nyata namun pada perlakuan pasir dan pupuk kandang memiliki angka tertinggi yaitu $54.89 \%$. Pengukuran persentase hidup dilakukan pada minggu ke8 setelah tanam. Ha ini mungkin di sebabkan karena pada perlakuan pasir dan pupuk kandang memiliki sifat fisik tanah yang mampu mempercepat pertumbuhan tanamn sukun. Tinggi persentase pada perlakuan pasir dan pupuk kandang diduga karena sifat pasir yang mudah menyerap air dan melepaska air. Hal ini di tambahkan oleh (Diraayandra, 2013) bahwa pasir memiliki pori-pori berukuran besar sehungga menjadi mudah basah dan cepat kering oeh proses penguapan. Kohesi dan kositensi (ketahanan terhadap proses pemisahan) pasir sangat kecil sehingga mudah terkikis oleh air atau angina.

\subsection{Persentase Hidup}

Berdasrkan hasil sidik ragam menunjukkan bahwa pengaruh beberapa media semai terhadapar pertumbuhab stek akar tanaman sukun tidak berpengaruh nyata terhadap persentase hidup (lampiran 3f)rerata persentase hidup dari stek akar tanaman sukun dari berbagai perlakuan dapat dilihat pada tabel 6.

\begin{tabular}{|c|c|}
\hline Perlakuan & $\begin{array}{l}\text { Rata- } \\
\text { rata }\end{array}$ \\
\hline \multirow{6}{*}{$\begin{array}{l}\text { (Pasir, dan Pupuk kandang) } \\
\text { (Pasir, Pupuk Kandang dan Tanah } \\
\text { Gambut) } \\
\text { (pasir, pupuk kandang, dan serbuk } \\
\text { gergaji) } \\
\text { (pasir, pupul kandang, dan arang } \\
\text { serbuk gergaji) } \\
\text { (pasir, pupuk kandang, dan sekam } \\
\text { padi) } \\
\text { (pasir, pupuk kandang, dan arang } \\
\text { sekam padi) }\end{array}$} & $50.00 \mathrm{a}$ \\
\hline & $2.3 .23 \mathrm{a}$ \\
\hline & $47.78 \mathrm{a}$ \\
\hline & $44.45 \mathrm{a}$ \\
\hline & $33.33 \mathrm{a}$ \\
\hline & 38.89 a \\
\hline
\end{tabular}

Angka-angka yang di ikutidakti o leh huruf pada kolom yang sama tidak berbeda nyata menurut BNJ pada taraf $5 \%$

Dari tabel 6 rerata persentase hidup diatas dapat dilihat bahwa setiap perlakuan menunjukan pengaruh tidak nyata akan tetapi di lihat dari rat-ratatertinggi pada perlakuan pasir dan pupuk kandang 50.00\%. hal ini di duga pada perlakuan pasir dan pupuk kandang mampu memberikan pertumbuhan terbaik pada tanaman sukun, karena pada pasir mempunyai sifat porositas, aerasi dan darinase yang baik pada pupuk kandang memiliki kandungan unsur hara yang cukup bagi tanaman sehingga taanaman dapat tumbuh dengan baik. Hal ini didukung oleh (Winarni,2009) kelembapan udara di sekitar stek harus tetap tinggi untuk mengurangi evavotranspirasiyang terjadi melalui daun, bagian tanaman lain dan media sehingga ketersedian air dalam tanaman tetap terjaga untuk menunjang proses metabolisme.

\subsection{Jumlah akar}

Berdasrkan hasil sidik ragam menunjukkan bahwa pengaruh beberapa media semai terhadapar pertumbuhab stek akar tanaman sukun berpengaruh nyata terhadap jumlah akar sukun (lampiran $3 \mathrm{~g}$ ) rerata persentase jumlah akar sukun dari stek akar tanaman sukun dari berbagai perlakuan dapat dilihat pada tabel 7.

\begin{tabular}{|l|l|}
\hline perlakuan & $\begin{array}{l}\text { Rata- } \\
\text { rata }\end{array}$ \\
\hline $\begin{array}{l}\text { (Pasi, pupuk kandang, dan arang } \\
\text { serbuk gergaji, dan Pupuk }\end{array}$ & 1.07 a \\
\cline { 2 - 2 } $\begin{array}{l}\text { kandang) } \\
\text { (Pasir, Pupuk Kandang dan Tanah }\end{array}$ & 2.97 a \\
\cline { 2 - 2 } $\begin{array}{l}\text { Gambut ) } \\
\text { (pasir, pupuk kandang, dan serbuk } \\
\text { gergaji) }\end{array}$ & 0.97 a \\
\cline { 2 - 2 } $\begin{array}{l}\text { (pasir, pupuk kandang, dan sekam } \\
\text { padi) } \\
\text { (pasir, pupuk kandang, dan arang } \\
\text { sekam padi) }\end{array}$ & 1.67 a \\
\cline { 2 - 2 } & 2.57 a \\
\end{tabular}

Angka-angka yang di ikutidakti o leh huruf pada kolom yang sama tidak berbeda nyata menurut BNJ pada taraf $5 \%$

Dari hasil pengamatan jumlah akar yang terdapat pada tabel 7 diatas bahwa perlakuan pasir dan pupuk kandang dan serbuk gergaji da perlakuan pasir, pupuk kandang dan arang sekam padi mampu meningkatkan jumlah akar pada stek tanaman sukun, hal ini diduga karena ada nya hormone yang tersedia dari kombinasi perlakuan serta hormone yang terdapat pada tanaman bibit sukun itu sendiri, hal ini ditambahkan lagi oleh (Jaellani, 2011). Terbentuk nya akar pada stek tanaman sukun merupakan indikasi keberhasilan dari stek. Adapun hal yang mempengaruhi pertumbuhan stek akar adalah faktor lingkungan dan faktor dalam tanaman.

\subsection{Bobot akar kering}

Berdasrkan hasil sidik ragam menunjukkan bahwa pengaruh beberapa media semai terhadap bobot akar kering tanaman sukun berpengaruh nyata terhadap bobot akar kering (lampiran 3h)rerata persentase hidup dari stek akar tanaman sukun dari berbagai perlakuan dapat dilihat pada tabel 8 .

\begin{tabular}{|l|l|}
\hline Perlakuan & $\begin{array}{l}\text { Rata- } \\
\text { rata }\end{array}$ \\
\hline (Pasi, pupuk kandang, dan arang & $0.71 \mathrm{a}$ \\
\cline { 2 - 2 } $\begin{array}{l}\text { serbuk gergaji, dan Pupuk kandang) } \\
\text { (Pasir, Pupuk Kandang dan Tanah }\end{array}$ & $0.91 \mathrm{a}$ \\
\cline { 2 - 2 } Gambut) & $1.05 \mathrm{a}$ \\
\cline { 2 - 2 } & $0.74 \mathrm{a}$ \\
\hline
\end{tabular}




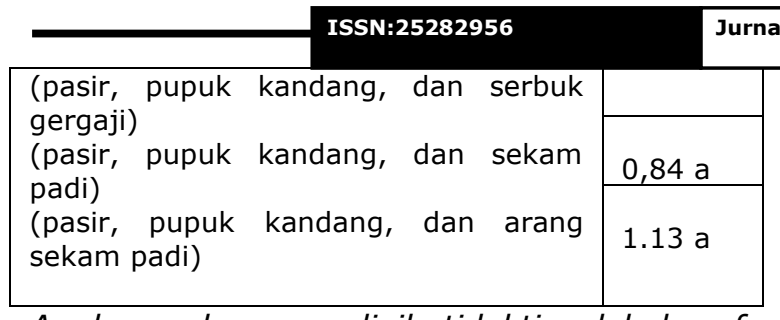

Angka-angka yang di ikutidakti o leh huruf pada kolom yang sama tidak berbeda nyata menurut BNJ pada taraf 5\%

Dilhat dari data tabel 8 diatas menunjukan bahwa bobot akar kering tertinggi yaitupada perlakuan pasir, pupuk kandang dan arang sekam padi 1.13. Hal ini diduga karena pada perlakuan pasir, pupuk kandang dan arang sekam padi selain mampu meningkatkan pertumbuhan akar pada stek juga mampu meningkat pertimbuhan pada tunas. Pertumbuhan daundan jumlah akar tanaman sukun.

\subsection{Indek mutu bibit}

Data hasi pengamatan indek mutu bibit setelah dilakukan analisisidik ragam bahwa pengaruh beberapa bahwa pengaruh beberapa mediasemai terhadap pertumbuhan stek akar tanaman sukun berpengaruh nyata. (lampiran.i).rata-rata indeks mutu bibit dari stek akar tanaman sukun dari berbagai perlakuan dapat dilihat pada tabel 9.

\begin{tabular}{|l|l|}
\hline Perlakuan & $\begin{array}{l}\text { Rata- } \\
\text { rata }\end{array}$ \\
\hline $\begin{array}{l}\text { (Pasi, pupuk kandang, dan arang } \\
\text { serbuk gergaj r, dan Pupuk kandang) } \\
\text { (Pasir, Pupuk Kandang dan Tanah }\end{array}$ & $0.47 \mathrm{a}$ \\
\cline { 2 - 2 } $\begin{array}{l}\text { Gambut ) } \\
\text { (pasir, pupuk kandang, dan serbuk }\end{array}$ & $0.70 \mathrm{a}$ \\
\cline { 2 - 2 } $\begin{array}{l}\text { gergaji) } \\
\text { (pasir, pupuk kandang, dan sekam }\end{array}$ & $0.42 \mathrm{a}$ \\
\cline { 2 - 2 } $\begin{array}{l}\text { padi) } \\
\text { (pasir, pupuk kandang, dan arang } \\
\text { sekam padi) }\end{array}$ & $0.51 \mathrm{a}$ \\
\hline
\end{tabular}

Angka-angka yang di ikutidakti o leh huruf pada kolom yang sama tidak berbeda nyata menurut BNJ pada taraf $5 \%$

Tabel diatas menunjukan bahwa perlakuan pasir, pupuk kandang dan serbuk gergaji. Mampu

tanaman sukun dalam media tanam, dari pengamatan indek mutu bibit yang dilakukan dari berbagai pengukuran berat kering tanamn total.diameter tunas berat kering tajuk dan berat kering akar. Maka didapatlah indeks mutu bibit yang menyatakan bibit layal tau tidak nya dipindahkan di lapangan. Karena menurut (frianto, 2007). Bahwa makkin besar angka indeks mutu bibit menandakan makin tunggi bibit. Serta bibit yang dalam wadah yang mempunyai angka indeks mutu bibit yang lebih kecildari 0.09 tidak akan berdaya tahan hidup yang tinggi jika ditanam di lapangan.

\section{KESIMPULAN}

\subsection{Kesimpulan}

Dari data hasil penelitian dapat di ambil kesimpulan sebagai berikut:

1. Beberap kombinasi media semai terhadap pertumbuhan stek akar tanaman sukun berpengaruh nyata pada parameter panjang tunas, panjang daun, jumlah daun, diameter tunas, persentasi tumbuh dan persentase hidup.

2. Dilihat dari para metr indeks mutu bibit dari semua perlakuan kombinasi cocok untuk pertumbuhan stek akar tanaman sukun, akan tetapi yang lebih baik dan menunjukan angka tertinggi yaitu perkuan pasir, pupuk kandang,dan serbuk gergaji 0.07

\section{2. saran}

Berdarkan hasil yang telah di simpukan maka di saran kan untuk untuk penelitian berikut nya perlu adanya penelitian lanjutan untuk penggunaan kombinasi media pasir dan pupuk kandang pasir, pupuk kandang dan tanah gambut, pasir, pupuk kandang dan sebuk gergaji, pasir, pupuk kandang dan arang sebuk gergaji,pasir pupuk kandang dan sekam padi, pasir, pupuk kandang dan arang sekam padi. Pada indeks mutu bibit pada umur 30, 60 dan 90 hari setelah tanam.

\section{DAFTAR PUTAKA}

adinugraha. (2007). pertubuhan stek pucuk dari hasil pemangkasan semai jenis eucalyptus pellita F. Pemulian tanaman hutan , 9.

bayu, j. g. (2013). laporan pembiakan vegetatif dengan cara stek(cuttage). universitas jember.

daulay D.S. (2010). pertubuhan stek akar sukun. medan: medan 2010.

dkk, m. (yogyakarta 2008). pertumbuhan tanaman pulai pada beberapa tinggi pangkasan dan dosis pupuk NPK. jurnal pemulian tanaman hutan vol.2 no. 2, 9.

irwanto. (2012, juli selasa). Retrieved from http//www.kapetseram.com/infosuk un.html.

pitojo setijo, i. (1992). budidaya sukun. yogyakarta: kanisus.

winarni. (maret 2009). repon pertumbuhan pulai terhadap komposisi media sapihtopsoil dan cocopeat dengan sistem koffco. jurnal hutan tropis borneo, 25. 